Date of publication: July 24, 2021

DOI: 10.52270/26585561_2021_11_13_34

Historical Sciences

\title{
SOCIAL MINISTRY OF THE RUSSIAN ORTHODOX CHURCH IN RUSSIA AT THE PRESENT STAGE
}

\author{
Mamaeva, Tatiana Sergeevna ${ }^{1}$ \\ ${ }^{1}$ Applicant, Voronezh State Technical University, 20 years of October street, 84, Voronezh, Russia, \\ E-mail: sofia2006@list.ru
}

\begin{abstract}
The article analyzes the historical background of social service in the Russian Orthodox Church at the present stage. As a result of the analysis of the materials, it was revealed that the comparison of moral and ethical standards with the real problems of our time makes it possible to form knowledge on the basis of which proven decisions can be made to achieve social stability in society.

A comprehensive study of the evolution of the social teaching of Russian Orthodoxy was carried out, in the course of which the main stages of its formation were determined; the factors and reasons that contributed to its appearance have been identified; the prospects for its further development are formulated.
\end{abstract}

Keywords: religion, society, church, person, state.

\section{INTRODUCTION}

Late XX - early XXI century in Russia were marked by serious socio-economic and political changes, as a result of which such negative phenomena as unemployment, poverty, professional and life insecurity, demographic crisis, a decrease in the authority of the family, an increase in the number of suicides and abortions, drug addiction and alcoholism, growth crime, allowing to talk about the spiritual degradation of Russians. The main misfortune of modern society is the rapid loss of spiritual guidance by people. Selfishness, cruelty, licentiousness, permissiveness, disrespect for the law become commonplace, turn into an everyday norm of life. In this situation, the problem of social assistance is especially acute.

World practice shows that social protection achieves maximum efficiency when, along with the state, the structures of civil society are included in it. In modern Russia, the Russian Orthodox Church (ROC) is an important institution of civil society, expressing its readiness to take an active part in resolving these problems. The church with its experience and traditions, commandments and prescriptions can help the state overcome moral inferiority and the whole complex of social ills.

She is able to confront the above problems by fostering in a person mercy, patience, compassion, modesty, honesty, the ability to put oneself in the place of others, love for people and respect for the interests of 
others. Thus, the relevance of the research topic is determined by the current social need of various groups of the population for social support, in connection with which the potential of the Russian Orthodox Church is in demand.

\section{METHODOLOGY}

The theoretical and methodological basis of the article is based on such cognitive procedures as philosophical reflection, heuristic traditions of analytical philosophy; systemic, activity-based, institutional, abstract-logical, phenomenological, hermeneutic and deterministic approaches, as well as structural-functional and comparative-historical research methods.

The study is based on the principle of a systematic approach, according to which the main areas of social service of the Russian Orthodox Church are considered as a holistic formation, deployed in a dynamic process, having external and internal resources for its own development. To study the internal structure of this social phenomenon, structural-functional analysis and an activity approach were used.

In this study, an institutional approach is also applied, which makes it possible to single out and consider sufficiently stable social processes and relations in which the Church participates, performing socially significant functions, as well as norms and regulations governing certain areas of human activity. The article actively uses the comparative-historical method, which makes it possible to compare the experience of social service to the Church at different stages of the development of society.

\section{RESULTS}

In social service, the Church finds the realization of her rich potential, that is, that set of means, sources, opportunities, resources and reserves with the help of which she, participating in the life of society, can influence the direction of social relations and shape their results. The social potential of the Russian Orthodox Church lies in its social teaching. This is a kind of guide for the socially oriented work of the church. Social learning includes teachings about society, socio-political, socio-economic, socio-ethical concepts. Its theological, theoretical foundations are the main ideas of Holy Scripture, the teachings of the Fathers of the Church, other spiritual authorities, decisions of the Councils of the Russian Orthodox Church, statements of patriarchs, studies of theologians, religious philosophers, sociologists. A detailed study of such a category of moral consciousness as mercy is of decisive importance for the formation of modern society, since the problem of social assistance in it is especially acute. Now more than ever it is necessary to instill in people the love, respect and compassion for which the Russian people were famous. Comparison of the moral and ethical ideas of thinkers with the real problems of our time makes it possible to form the necessary knowledge base, on the basis of which it is possible to make proven, proven decisions to achieve social stability in society, to carry out transformations. it is in the interests of man. The category of "mercy", analyzed in a broad socio-philosophical context by the Russian religious philosophy of the late 19th - early 20th centuries, in modern conditions again acquires significance for the public service of the Russian Orthodox Church as value guidelines for practical training. The social teaching of the Russian Orthodox Church has been formed since the adoption of Christianity and took place in its formation for over a thousand years. But historical conditions until the end of the twentieth century did not allow the Russian Church to formulate its own social teaching. 


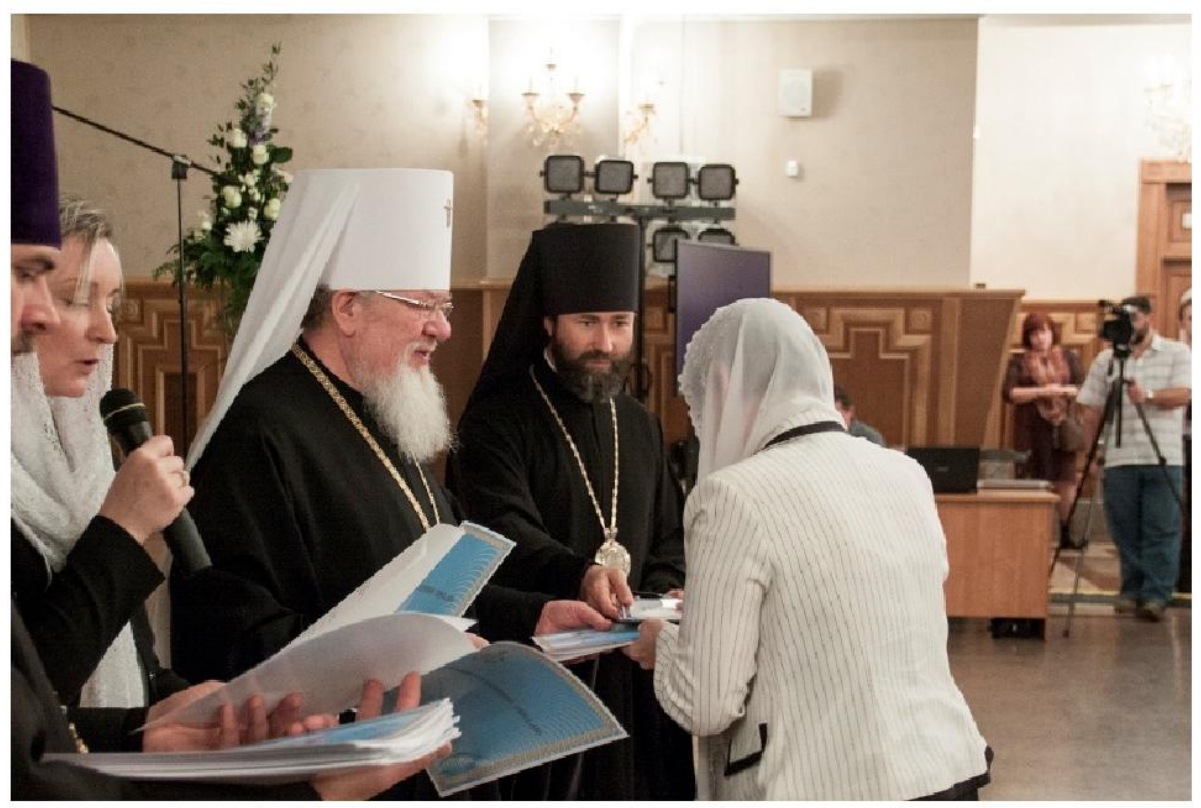

Only at the end of the twentieth century, after the liberation from communism, the Church faced the problem of creating a single treatise on the views of the Church on the social problems of our time with the proposal of ways to solve them. The appearance of the "Fundamentals of the Social Concept of the Russian Orthodox Church" is an event of both a pan-Orthodox and a Russian scale.

For the first time, the Russian Orthodox Church received a program of social service, and the society was informed about the position of the Church on the entire set of social issues. The importance of this document lies, first of all, in the ideological assessment of the changes taking place in society, a critical and at the same time benevolent indication of deviation from moral norms and ignorance of spiritual values, in determining the paths of spiritual and spiritual development. moral revival and solution of socially significant problems. However, with the adoption of the Fundamentals of the Social Concept of the Russian Orthodox Church, the process of forming the social doctrine is not completed, but continues in numerous documents of the Councils of Bishops and resolutions of the Holy Synod, the last of which are dated March 2010. In the early 1990s, the Voronezh diocese became an important subject of charitable activities. With the aim of reviving social service at the general diocesan level, the Department of Charity and Social Services, the Department of Missionary Activities, the Department for Relations with Military and Law Enforcement Agencies, the Department of Religious Education and Youth Ministry were created, which coordinated the efforts of monasteries and parishes in this type of activity. The diocese has entered into cooperation agreements with the Ministry of Education, Emergencies, Internal Affairs, Health and Social Protection. Social services at the present stage are extremely versatile in directions, forms and methods. 


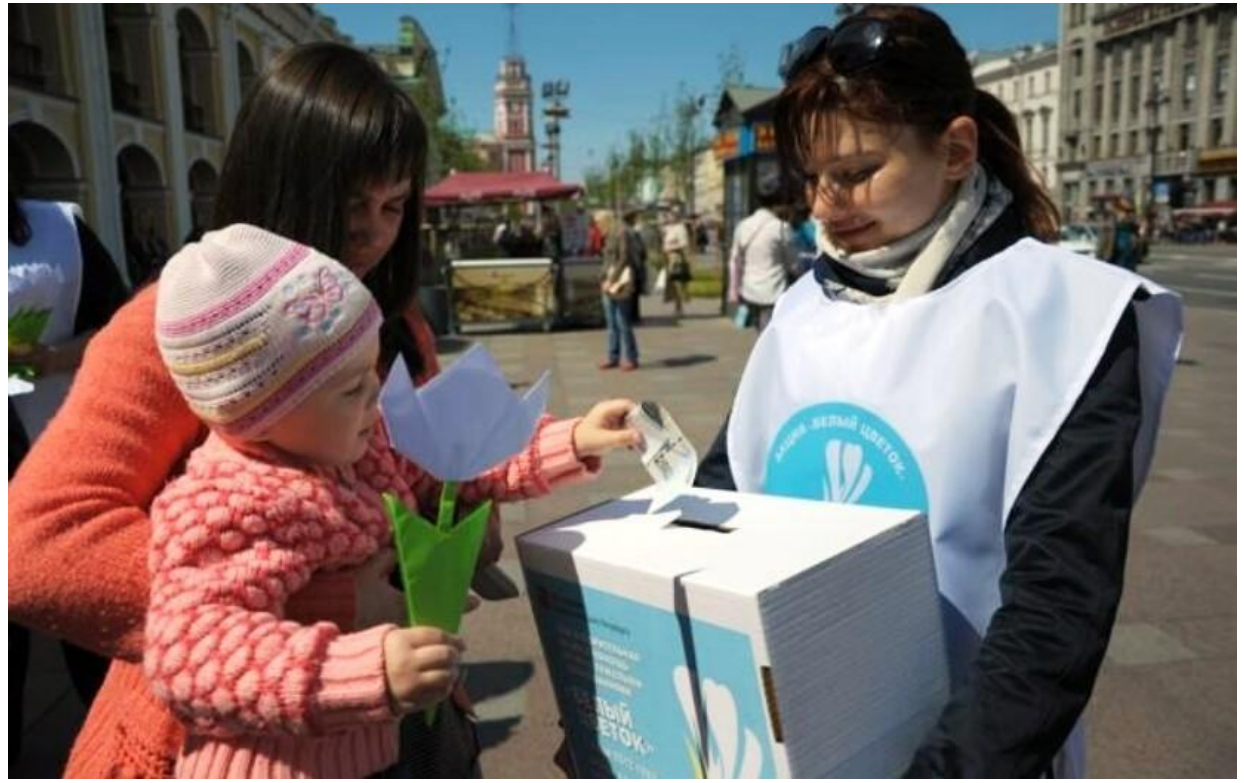

Help for refugees; migrants; victims of ethnic hatred; homeless people in extreme situations; distribution of humanitarian aid; organization of charitable canteens; caring for lonely elderly people at home; work with families, youth, prisoners and people suffering from mental illness, children from disadvantaged families, orphanages and boarding schools; prevention and rehabilitation of alcoholism and drug addiction; human rights activities; work in the Armed Forces and law enforcement agencies are the main directions of the charitable work of the Church. They are conditioned by the need of the state for the participation of the Church in social support of the population. All this allows us to speak about the already established regional system of social service to the Church.

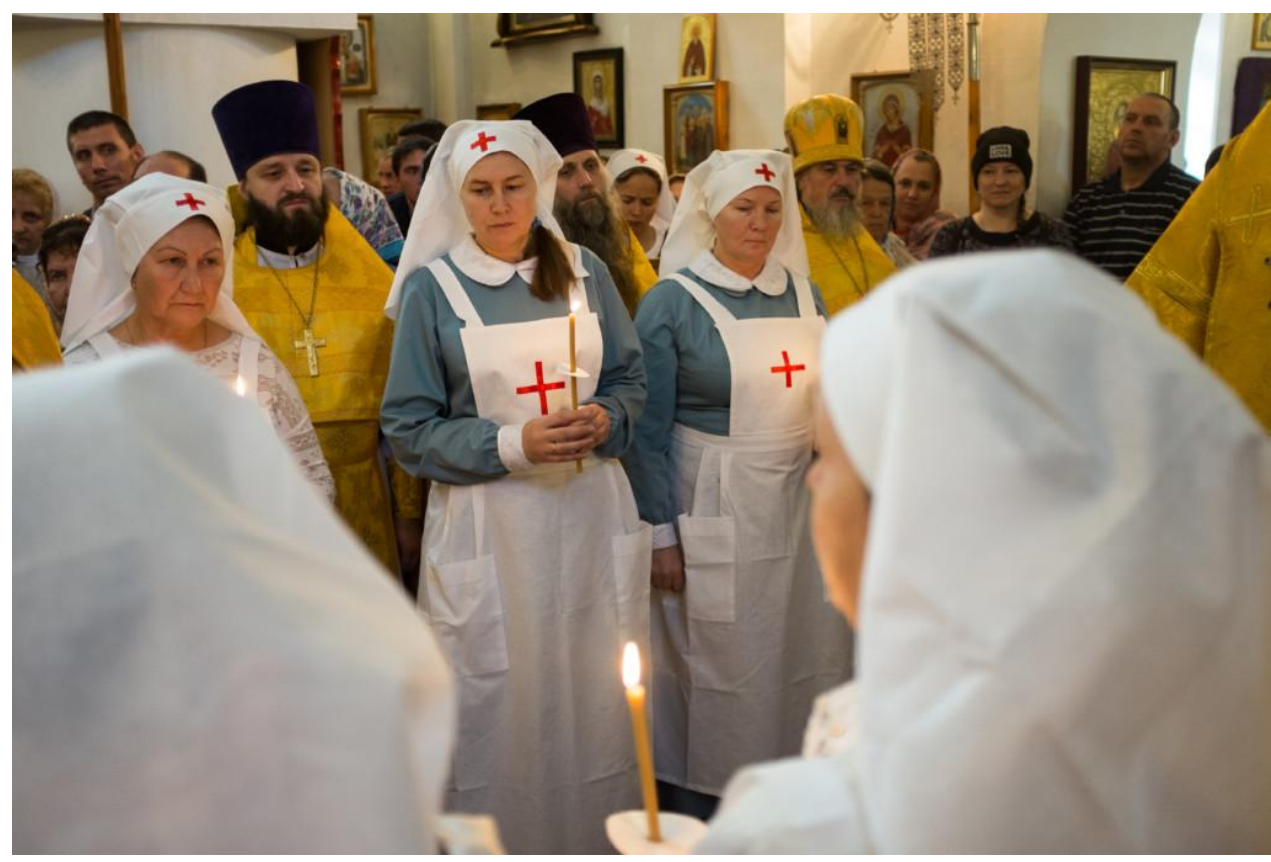


A separate area of the Church's ministry is the prevention and treatment of alcoholism and drug addiction. The Russian Orthodox Church works in the field of preventive anti-drug education, influencing public opinion, and also helps in the rehabilitation of people who want to free themselves from drug and alcohol addiction, creating Orthodox rehabilitation centers for drug addicts. However, the activities of such rehabilitation centers are outside the legal framework. It is necessary to develop a special law on rehabilitation activities, in which the Russian Orthodox Church can also take part.

\section{CONCLUSION}

Thus, the Russian Orthodox Church is capable of finding solutions to individual problems of the social sphere at a professional level, becoming a full-fledged participant in the life of society, and its social service is a factor in the sustainable development of the state in general and regional society in particular. In modern times, the main challenge for the Church is to find new forms of social service that meet the needs of individuals, families and society, while at the same time promoting social justice at the national and regional levels.

\section{REFERENCE LIST}

Bakhmustov S. B. (2006) From the history of spiritual culture of the Mordovian region: local history essays. Saransk: Type. "Red October". 176 p. (in Russ).

Bortnikova O. N. (1999) Orthodox prison Churches (historical aspect). Fundamentals of State and Law. №. 5. Pp. 61-63. (in Russ).

Bulgakov S. N. (1997) Two grads. Studies on the nature of social ideals. St. Petersburg: Publishing House of the Russian Academy of Sciences. 589 p. (in Russ).

Chekmeneva T.G., Ershov B.A., Trubitsyn S.D., Ostapenko A.A. (2020) Chinas Information Security Strategy: Political and Technical Aspects. Bulletin Social-Economic and Humanitarian Research. Volume 7. Number 9. Pp. 78 - 97. doi: 10.5281/zenodo.3911320 (in Russ).

Deryabin P. (1878) On Christian charity according to the teaching of the Holy Fathers. M.: Public American typolitography of Yu. M. Hoffman on Tverskaya. 154 p. (in Russ).

Ershov B.A. (2010) The Russian Orthodox Church and secular power in the Voronezh province in the XIX - early XX centuries. GOU VPO "Voronezh State Technical University". Voronezh. 167 p. (in Russ).

Ershov B.A. (2010) The system of spiritual education in Voronezh province in the 19th century. Education and Society. №. 5 (64). Pp. 105-108.

Ershov B.A., Fursov V.N. (2018) The Russian Church in the State Mechanism of Russia. Bulletin SocialEconomic and Humanitarian Research. № 1. Pp. 32-37. (in Engl).

Ershov B.A., Perevozchikova L.S., Romanova E.V. (2019) Globalization and Intensification of Spiritual Values in Russia in the Philosophical Aspect. 6th International Conference on Education and Social Sciences Abstracts \& Proceedings. Pp. 208-212. (in Engl).

Ershov B.A., Perevozchikova L.S., Romanova E.V., Ashmarov I.A. (2019) The Concept of Spirituality in Social Philosophy. Smart Innovation, Systems and Technologies. T. 139. Pp. 688-694. (in Engl).

Frolov M. I. (2004) Military clergy in Russia. Voenno-ist. journal. №. 11. P. 79. (in Russ). 

Russ).

Gordienko N. S. (1984) Evolution of Russian Orthodoxy (20-80 gg. XX century.). M.: Znanie. 64 p. (in

Ilyin I. A. (1992) Niches of the problem. The historical fate and future of Russia. Articles from 1948-1954. In 2 vols. M: Rarog. 616 p. (in Russ).

Klyuchevsky V. O. (1997) Good People of Ancient Russia. Historical portraits. M.: Publishing House "Zachatievsky monastery". 234 p. (in Russ).

Kuznetsov A. (2000) The clergy and traditions of the fleet Svyaz VMF Rossii i RPSHCH. Morskoy sbornik. №. 2. Pp. 57-61. (in Russ).

Mchedlov M. P. (2005) Religious studies essays. Religion in the spiritual and socio-political life of modern Russia. M.: Nauch. kn. 447 p. (in Russ).

Mitrokhin N. (2004) The Russian Orthodox Church: the current state and actual problems. M.: Novoe literaturnoe obozrenie. 650 p. (in Russ).

Mochalov E. V. (2003) Analysis of anthropological problems in the Russian Philosophy of Unity of the XIXXX centuries: diss. . doct. philos. Saransk. 339 p. (in Russ).

Pashentsev D. A. (1995) Charity activity of the Russian Orthodox Church in the second half of the XIXbeginning of the XX century: dis. kand. ist. nauk: 07.00.02. M. 188 p. (in Russ).

Roik V. (2004) Social doctrine of Christianity. Man and Labor. №. 1. Pp. 62-65. (in Russ).

Trainin O. M. (2003) The role of the Christian Church in the formation of the Institute of Charity. Law. №. 10. Pp. 75-76. (in Russ).

Zubanova S. G. (2002) Social service of the Russian Orthodox Church in the XIX century: dis. . doctor of Historical Sciences: 07.00.02. M. 408 p. (in Russ). 


\title{
СОЦИАЛЬНОЕ СЛУЖЕНИЕ РУССКОЙ ПРАВОСЛАВНОЙ ЦЕРКВИ В РОССИИ НА СОВРЕМЕННОМ ЭТАПЕ
}

\author{
Мамаева Татьяна Сергеевна ${ }^{1}$ \\ ${ }^{1}$ Соискатель, Воронежский государственный технический университет, улица 20-летия Октября, \\ 84, Воронеж, Россия, E-mail: sofia2006@list.ru
}

\begin{abstract}
Аннотация
В статье анализируются исторические предпосылки социального служения В Русской Православной Церкви на современном этапе. В результате анализа материалов было выявлено, что сопоставление морально-этических норм с реальными проблемами современности позволяет сформировать знания, на основе которых могут приниматься проверенные решения для достижения социальной стабильности в обществе. Проведено комплексное исследование эволюции социального учения русского православия, в ходе которого определены основные этапы его становления; выявлены фракторы и причины, способствовавшие его появлению; сформулированы перспективы его дальнейшего развития.
\end{abstract}

Ключевые слова: религия, общество, церковь, человек, государство.

\section{СПИСОК ЛИТЕРАТУРЫ}

Bakhmustov S. B. (2006) From the history of spiritual culture of the Mordovian region: local history essays. Saransk: Type. "Red October". 176 p. (in Russ).

Bortnikova O. N. (1999) Orthodox prison Churches (historical aspect). Fundamentals of State and Law. №. 5. Pp. 61-63. (in Russ).

Bulgakov S. N. (1997) Two grads. Studies on the nature of social ideals. St. Petersburg: Publishing House of the Russian Academy of Sciences. 589 p. (in Russ).

Chekmeneva T.G., Ershov B.A., Trubitsyn S.D., Ostapenko A.A. (2020) Chinas Information Security Strategy: Political and Technical Aspects. Bulletin Social-Economic and Humanitarian Research. Volume 7. Number 9. Pp. 78 - 97. doi: 10.5281/zenodo.3911320 (in Russ).

Deryabin P. (1878) On Christian charity according to the teaching of the Holy Fathers. M.: Public American typolitography of Yu. M. Hoffman on Tverskaya. 154 p. (in Russ).

Ershov B.A. (2010) The Russian Orthodox Church and secular power in the Voronezh province in the XIX - early XX centuries. GOU VPO "Voronezh State Technical University". Voronezh. 167 p. (in Russ).

Ershov B.A. (2010) The system of spiritual education in Voronezh province in the 19th century. Education and Society. №. 5 (64). Pp. 105-108.

Ershov B.A., Fursov V.N. (2018) The Russian Church in the State Mechanism of Russia. Bulletin SocialEconomic and Humanitarian Research. № 1. Pp. 32- 37. (in Engl). 
Ershov B.A., Perevozchikova L.S., Romanova E.V. (2019) Globalization and Intensification of Spiritual Values in Russia in the Philosophical Aspect. 6th International Conference on Education and Social Sciences Abstracts \& Proceedings. Pp. 208-212. (in Engl).

Ershov B.A., Perevozchikova L.S., Romanova E.V., Ashmarov I.A. (2019) The Concept of Spirituality in Social Philosophy. Smart Innovation, Systems and Technologies. T. 139. Pp. 688-694. (in Engl).

Frolov M. I. (2004) Military clergy in Russia. Voenno-ist. journal. №. 11. P. 79. (in Russ). Russ).

Gordienko N. S. (1984) Evolution of Russian Orthodoxy (20-80 gg. XX century.). M.: Znanie. 64 p. (in

Ilyin I. A. (1992) Niches of the problem. The historical fate and future of Russia. Articles from 1948-1954. In 2 vols. M: Rarog. 616 p. (in Russ).

Klyuchevsky V. O. (1997) Good People of Ancient Russia. Historical portraits. M.: Publishing House "Zachatievsky monastery". 234 p. (in Russ).

Kuznetsov A. (2000) The clergy and traditions of the fleet Svyaz VMF Rossii i RPSHCH. Morskoy sbornik. №. 2. Pp. 57-61. (in Russ).

Mchedlov M. P. (2005) Religious studies essays. Religion in the spiritual and socio-political life of modern Russia. M.: Nauch. kn. 447 p. (in Russ).

Mitrokhin N. (2004) The Russian Orthodox Church: the current state and actual problems. M.: Novoe literaturnoe obozrenie. 650 p. (in Russ).

Mochalov E. V. (2003) Analysis of anthropological problems in the Russian Philosophy of Unity of the XIXXX centuries: diss. . doct. philos. Saransk. 339 p. (in Russ).

Pashentsev D. A. (1995) Charity activity of the Russian Orthodox Church in the second half of the XIXbeginning of the XX century: dis. kand. ist. nauk: 07.00.02. M. 188 p. (in Russ).

Roik V. (2004) Social doctrine of Christianity. Man and Labor. №. 1. Pp. 62-65. (in Russ).

Trainin O. M. (2003) The role of the Christian Church in the formation of the Institute of Charity. Law. №. 10. Pp. 75-76. (in Russ).

Zubanova S. G. (2002) Social service of the Russian Orthodox Church in the XIX century: dis. . doctor of Historical Sciences: 07.00.02. M. 408 p. (in Russ). 